Digitized by the Internet Archive in 2016

https://archive.org/details/distributionrela00scho_0 


\title{
Distribution and Relative Abundance of Small Mammals of the Western Plains of Alberta as Determined from Great Horned Owl Pellets
}

\author{
D. (Tim) Schowalter
}

Alberta Species at Risk Report No. 17

May 2001

Published by:

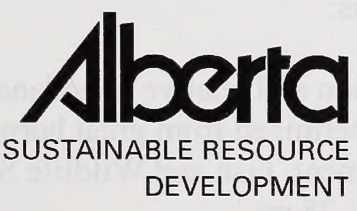


Publication No.: I/022

ISBN: 0-7785-1792-6 (Printed Edition)

ISBN: 0-7785-1793-4 (On-line Edition)

ISSN: 1496-7219 (Printed Edition)

ISSN: 1496-7146 (On-line Edition)

Illustration: Brian Huffman

For copies of this report, contact:

Information Centre - Publications

Alberta Environment / Alberta Sustainable Resource Development

Main Floor, Great West Life Building

9920108 Street

Edmonton, Alberta

Canada

T5K 2M4

Telephone: (780) 422-2079

\section{OR}

Information Service

Alberta Environment / Alberta Sustainable Resource Development

\#100, 311512 Street NE

Calgary, Alberta

Canada

T2E $7 \mathrm{~J} 2$

Telephone: (403) 297-3362

This publication may be cited as:

Schowalter, D. 2001. Distribution and relative abundance of small mammals of the western plains of Alberta as determined from great horned owl pellets. Alberta Sustainable Resource Development, Fish and Wildlife Service, Alberta Species at Risk Report No. 17. Edmonton, AB. 28 pp. 


\section{TABLE OF CONTENTS}

ACKNOWLEDGEMENTS ...................................................................................... vi

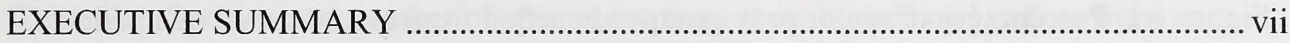

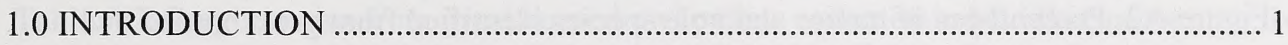

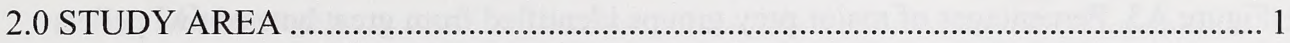

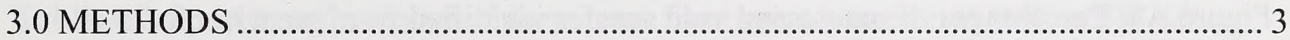

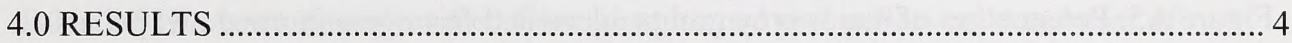

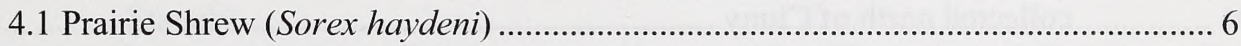

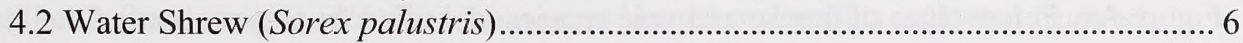

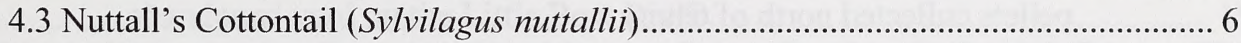

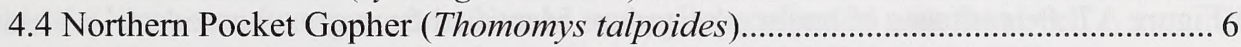

4.5 Olive-backed Pocket Mouse (Perognathus fasciatus) ............................................. 6

4.6 Deer Mouse (Peromyscus maniculatus) ………................................................... 7

4.7 Northern Grasshopper Mouse (Onychomys leucogaster) ...................................... 7

4.8 Long-tailed Vole (Microtus longicaudus) ............................................................ 7

4.9 Prairie Vole (Microtus ochrogaster) ……….................................................... 7

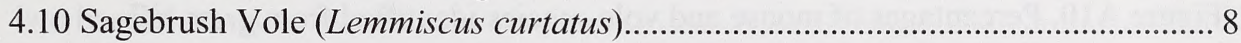

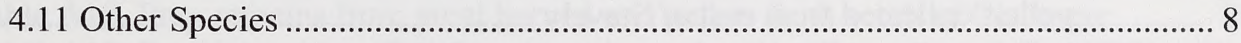

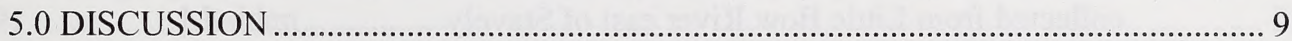

6.0 MANAGEMENT IMPLICATIONS AND FUTURE DIRECTIONS ........................ 9

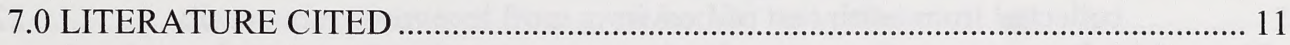

Appendix A. Site-specific Results and Descriptions ……............................................ 12

Appendix B. Voucher Specimens Submitted to the University of Alberta Museum of Zoology 


\section{LIST OF FIGURES}

Figure 1. Locations of owl pellets collected for analysis during spring and summer of 2000

Figure A1. Percentages of major prey groups identified from great horned owl pellets collected from Middle Coulee

Figure A2. Percentages of mouse and vole species identified from great horned owl pellets collected from Middle Coulee

Figure A3. Percentages of major prey groups identified from great horned owl pellets collected east of Carmengay

Figure A4. Percentages of mouse and vole species identified from great horned owl pellets collected east of Carmengay

Figure A5. Percentages of major prey groups identified from great horned owl pellets collected north of Cluny

Figure A6. Percentages of mouse and vole species identified from great horned owl pellets collected north of Cluny

Figure A7. Percentages of major prey groups identified from great horned owl pellets collected from SW of Standard

Figure A8. Percentages of mouse and vole species identified from great horned owl pellets collected from SW of Standard

Figure A9. Percentages of major prey groups identified from great horned owl pellets collected from east of Stavely

Figure A10. Percentages of mouse and vole species identified from great horned owl pellets collected from east of Stavely

Figure A11. Percentages of major prey groups identified from great horned owl pellets collected from Little Bow River east of Stavely

Figure A12. Percentages of mouse and vole species identified from great horned owl pellets collected from Little Bow River east of Stavely

Figure A13. Percentages of major prey groups identified from great horned owl pellets collected from northwest of Leavitt

Figure A14. Percentages of mouse and vole species identified from great horned owl pellets collected from NW of Leavitt

Figure A15. Percentages of major prey groups identified from great horned owl pellets collected from along Waterton River

Figure A16. Percentages of major prey groups identified from great horned owl pellets collected from NW Madden

Figure A17. Percentages of mouse and vole species identified from great horned owl pellets collected from NW Madden

Figure A18. Percentages of major prey groups identified from great horned owl pellets collected north of Cowley

Figure A19. Percentages of mouse and vole species identified from great horned owl pellets collected north of Cowley 


\section{LIST OF TABLES}

Table 1. Collection site and identified prey items from great horned owl pellets collected in the spring and summer of 2000 from the western plains of Alberta. 5

Table A1. Species and number of specimens from great horned owl pellets from under bridge east of Hayes.

Table A2. Prey remains from great horned owl pellets collected in Middle Coulee......... 14

Table A3. Numbers of identified prey items from great horned owl pellets east of Carmengay

Table A4. Numbers of prey from great horned owl pellets from north of Cluny. 16

Table A5. Species and number of prey items from great horned owl pellets SW of Standard.

Table A6. Prey remains identified from great horned owl pellets collected east of Stavely.

Table A7. Prey remains identified from great horned owl pellets collected from an abandoned yard on the Little Bow River

Table A8. Prey remains from great horned owl pellets collected near Swalwell 20

Table A9. Prey remains from great horned owl pellets collected south of Mountain View.

Table A10. Prey remains from great horned owl pellets collected northwest of Leavitt

Table A11. Prey remains from great horned owl pellets collected from along Waterton River. 23

Table A12. Prey remains from great horned owl pellets from south of Cochrane 24

Table A13. Prey items identified from great horned owl pellets collected from NW Madden 25

Table A14. Prey remains from great horned owl pellets from north of Cowley. 26

Table B1. Specimen numbers of voucher specimens placed in the collections of the University of Alberta Museum of Zoology of significant small mammal discoveries recovered from great horned owl pellets 28 
The consent of landowners who gave permission to search for and collect owl pellets in their buildings is gratefully acknowledged. Mr. Ed Sloboda of Warner arranged for access to the Middle Coulee site.

Dr. Gordon Court of the Fisheries and Wildlife Management Division recognised the potential value of this research and provided funding.

This project was completed when the Fisheries and Wildlife Management Division was part of Alberta Environment; this division is now part of Alberta Sustainable Resource Development. 


\section{EXECUTIVE SUMMARY}

Prey remains in great horned owl pellets from roosts in buildings on the western plains of Alberta were identified. The goal of the research was to obtain information on the relative abundance and distribution of small mammals in that area. Several species that were recovered were identified as being of concern or of unknown status in the 1996 Status of Alberta Wildlife Report (Alberta Environmental Protection 1996).

New distribution or significant marginal distribution records were obtained for prairie shrew, water shrew, Nuttall's cottontail, northern pocket gopher, olive-backed pocket mouse, northern grasshopper mouse, long-tailed vole, prairie vole and sagebrush vole. As well, specimens of deer mouse with unusual dental characteristics were recovered from west of the Porcupine Hills.

The absence of northern grasshopper mouse from several sites at comparatively high elevation suggests that the general limit of distribution of the species may be within the area examined. Similarly, sagebrush voles were absent from a sample from suitable habitat north of Calgary which suggests that the limit of that species' distribution was also encountered. Considerable further work is needed to confirm those observations.

Grasshopper mice and sagebrush voles were widely distributed and relatively abundant. Similar results have been obtained from analyses of owl pellet samples from the remainder of the plains and southern parklands. It is probable that populations of those two species in the province are secure.

Prairie voles were found to occur as far south as a site west of Calgary. This is a considerable expansion of the known distribution of the species, but is within the Aspen Parkland ecoregion, as are most previous records of prairie voles in Alberta. Prairie voles appear to have a defined distribution and, at best, a moderate abundance in the province. However, it is likely that the species is common enough that study of its biology would be practical.

Continued research on mammal distributions and abundance through the use of owl pellets is likely to be productive. However, a review and evaluation of the accumulated data is needed to provide direction for future efforts.

Editor's Note: Since this report was written, the general status of many of the species discussed within it has changed. In the case of the northern grasshopper mouse and the sagebrush vole, the results of this study contributed to their being ranked as Secure. All of the species discussed in this report now have the general status of Secure, except for the olive-backed pocket mouse, which is Sensitive, and the prairie vole, which is Status Undetermined. 


\subsection{INTRODUCTION}

Past examination of owl pellets has provided considerable information on the distribution and relative abundance of small mammals in the province of Alberta (Schowalter and Digby 1997, 1999; Smith 1981, 1992). Of particular interest to wildlife managers was that sagebrush voles and northern grasshopper mouse, both species of conservation concern (Alberta Environmental Protection 1996), were captured frequently by owls and occasionally at localities outside the known distribution of the species.

Owl pellets also provided information on several other species that are identified as being of possible conservation concern, such as Nuttall's cottontail, prairie vole, northern flying squirrel and olive-backed pocket mouse.

The samples of great horned owl pellets examined in this study were primarily collected from the plains and southern parkland of the province. An earlier study (Schowalter 2000) focused on filling in the largest gaps between samples in that area. Significant information on Ord's kangaroo rat, olive-backed pocket mouse, northern flying squirrel, northern grasshopper mouse, sagebrush vole and other species was obtained.

As owl pellets had not been extensively examined before in the area, the current study was undertaken to examine owl pellets from the western plains of Alberta. Several species of conservation concern are likely at the limits of their distribution in this region. Information on their relative abundance and general habitat associations would be of value in developing management strategies.

\subsection{STUDY AREA}

The current study is an expansion of analyses of owl pellets from the plains and parklands of central and southern Alberta (Schowalter and Digby 1997, 1999; Smith 1981, 1992). A large area of the western grasslands and adjacent parklands had not been sampled, so collection activity for this study focused on obtaining samples from that region (Figure 1). All sample locations are partially or completely located in areas of grassland. Brome and crested wheat grass, as is usual for farmyards, have invaded areas around the collecting sites to varying degrees. Generally, at least some land near the site had once been cultivated and then converted to tame hay or grazing land. The samples from Madden and tiny samples from Mountain View and Cochrane are from areas of mixed grassland and aspen clones. The Waterton River sample is from a prairie river valley with a riparian area dominated by cottonwoods. An extensive irrigation system occurs at the Standard location. Much of the area is irrigated and the native grassland at the collection site has a small flowing canal and considerable areas of high moisture. Major irrigation canals pass close to the Middle Coulee and Leavitt collection sites; however, most of the land near both sites is dry native grassland. Other samples are from prairie locations where trees, if present, are almost all planted to form windbreaks around the buildings. 


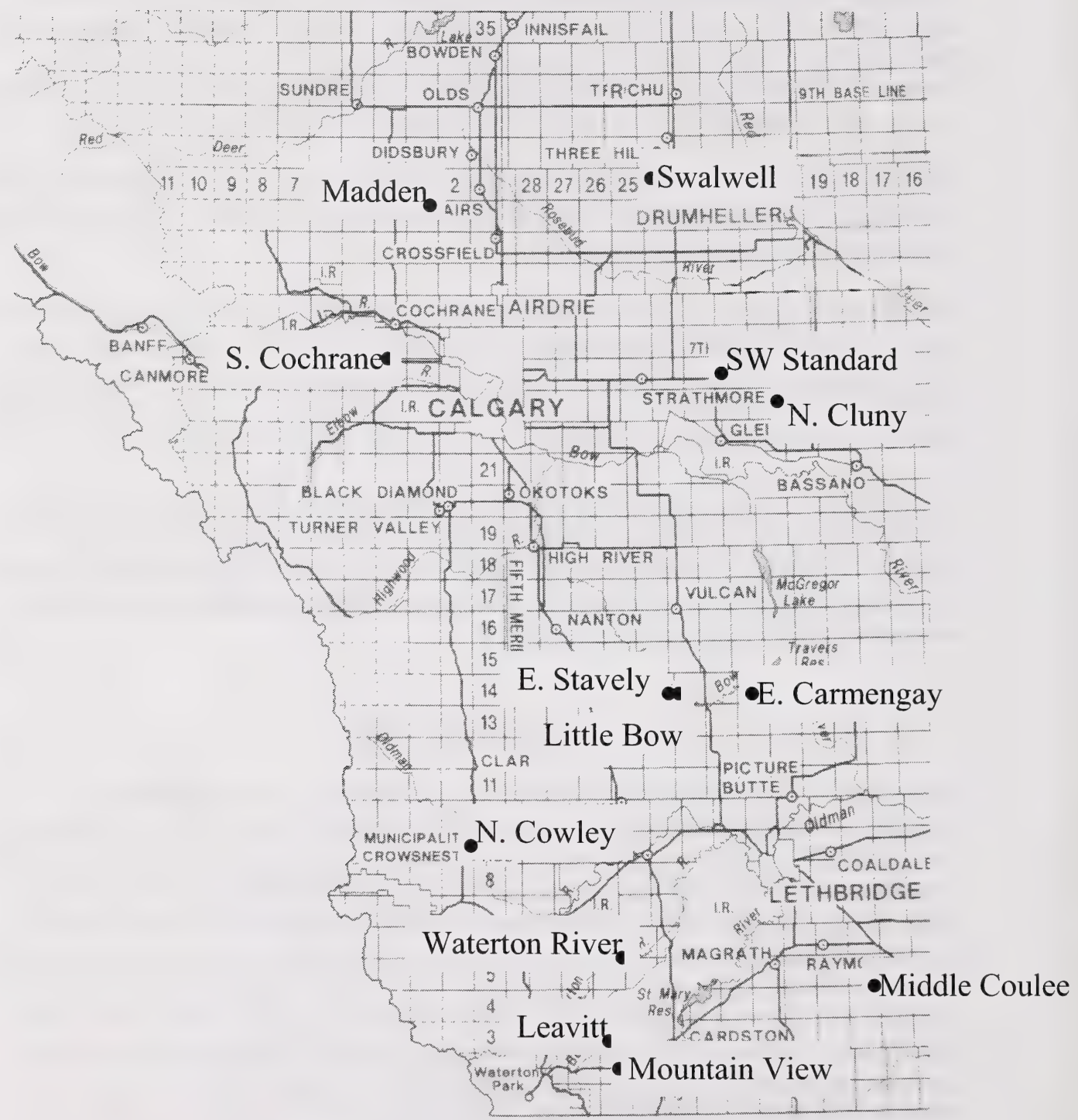

Figure 1. Locations of owl pellets collected for analysis during spring and summer 2000. 


\subsection{METHODS}

Collections of pellets were made only at roosts that were adjacent to at least some area of remaining native habitat. Several roosts were situated in areas that were primarily under cultivation or tame hay.

Pellets from the Madden sample were stored loose in a paper bag prior to sorting. For the other samples, pellets were placed individually in small paper bags and stored in large plastic bags that were not sealed. Storage in paper and unsealed plastic bags has been found to prevent growth of mould when there is damp material present. Broken pellets and loose material (when present) from all locations were saved as a grouped 'miscellaneous' sample in paper bags.

The treatment of pellets and other protocols are modified from those of Craighead and Craighead (1956). Pellets were teased apart manually using dental tools. All material was sorted at least twice. Identifiable remains were set aside during the sorting process. Records of items identified from separate pellets were made but are not included here.

Identifications of mammals were made using a dissecting microscope and a small comparative collection. Uncertain identifications were confirmed by comparison to reference material in the University of Alberta Museum of Zoology. Identification of non-mammalian prey was not attempted beyond easily ranked higher taxonomic levels.

Counts of individual mice, voles, shrews and pocket gophers were usually based upon the greater number of left or right mandibles. Rarely, the number of crania of a species exceeded the number of left or right mandibles. In those cases, the number of crania was used as the number of individuals. The method assumes that all of the bones of an individual are to be found in a single pellet; however, the occurrence of single mandibles of individuals in some pellets was noted. While it is not possible to know where the owl cast the pellet containing the rest of a given individual animal's bones, it is assumed that a small increase in the number of each species counted resulted. It is also assumed that the possibility of identifiable bones of an individual animal being found in more than one pellet is approximately equal for all small mammal species. If that is in fact the case, then the relative proportions of the different small mammals species should not be affected by this counting method.

Counts of larger mammals are based upon the minimum number of individuals for the entire sample. Remains of individuals of common mammalian prey, such as hares, rabbits and muskrats, occur in several pellets. Broken bones from different pellets can occasionally be fit together. Individuals were identified by considering individual element count, size, closure of epiphyses and cranial sutures, dental eruption and wear, and seasonal changes of hair colour. The method is likely to produce a lower count of individuals than was actually present, as it is not expected that all will be successfully separated. However, the number of large prey at most sites is small, so it is expected that few individuals were not counted. 
Separation of masked shrew (Sorex cinereus) and prairie shrew (Sorex haydenii) material found in owl pellets is sometimes difficult. Fortunately, the distinguishing characteristics of the two species have been examined in detail by van Zyll de Jong (1980). Fragmentary cranial material can be positively identified by the position of the infraorbital foramen. However, shrew mandibles are often not associated with crania in the pellets. Compared to masked shrews, prairie shrews have shorter, robust, heavily pigmented dentitions set in a robust mandible. Specimens in good condition generally can be assigned based on measurements and dental characteristics. Deeply etched, worn, or otherwise damaged examples may not be identifiable and are not assigned to either species here.

\subsection{RESULTS}

Table 1 summarises the results for all locations and should be referred to for comparison between samples. Detailed site information can be found in Appendix 1. Collection locations are mapped on Figure 1 and voucher specimens are listed in Appendix 2. Data on species of concern and notable locations have been entered into Alberta Sustainable Resource Development's Biodiversity/Species Observation Database (BSOD). 
Table 1. Collection site and identified prey items from great horned owl pellets collected in the spring and summer of 2000 from the western plains of Alberta.

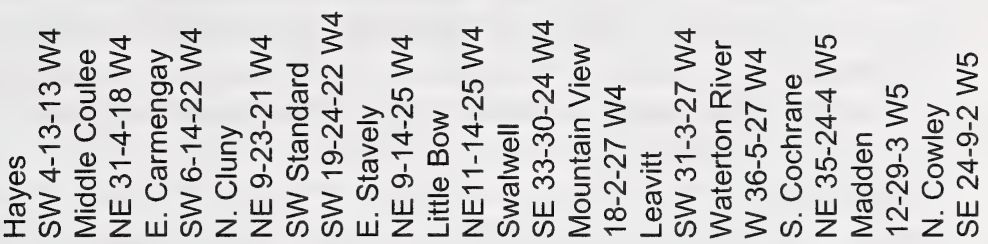

\begin{tabular}{|c|c|c|c|c|c|c|c|c|c|c|c|c|c|c|}
\hline Common Shrew & & & & & & 2 & 5 & & & & & & 4 & \begin{tabular}{|l|}
1 \\
\end{tabular} \\
\hline Prairie Shrew & 1 & 1 & 2 & 1 & & 1 & 12 & & & & 1 & & & 11 \\
\hline Prairie or Common Shrew & & 1 & 1 & & 1 & & 3 & & & 3 & 1 & & & 2 \\
\hline Dusky Shrew & & 1 & & & & 1 & 3 & & & & & & & 1 \\
\hline Water Shrew & & & & & & & & & & & & & 1 & \\
\hline Silver-haired Bat & & & & & & 1 & & & & & & & & \\
\hline \begin{tabular}{|l} 
Cottontail \\
\end{tabular} & 1 & & 2 & 3 & & & & & & & 1 & & & \\
\hline Jackrabbit & & 2 & 1 & 1 & & 8 & 7 & & & & & & & \\
\hline Snowshoe Hare & & & & & & & & & & & & & & 4 \\
\hline Richardson's G.S. & & 5 & 7 & 2 & 5 & 5 & 6 & & & 4 & & & 3 & \\
\hline Pocket Mouse & & 1 & & & & & & & & & & & & \\
\hline Pocket Gopher & & & & & & & & & & 34 & & 1 & 29 & 8 \\
\hline Deer Mouse & 1 & 399 & 168 & 195 & 190 & 280 & 228 & 16 & & 118 & 3 & 4 & 130 & 114 \\
\hline Grasshopper Mouse & & 21 & 28 & 5 & 7 & 88 & 21 & & & & & & & \\
\hline Meadow Vole & & 37 & 20 & 22 & 28 & 26 & 65 & 2 & 2 & 38 & 16 & 1 & 49 & 53 \\
\hline Long-tailed Vole & & & & & & & & & & 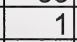 & & & 2 & \\
\hline Sagebrush Vole & & 30 & 40 & 15 & 1 & 97 & 15 & & 1 & 22 & & & & 37 \\
\hline Prairie Vole & & & & & & & & & & & & 1 & 23 & \\
\hline Muskrat & & 1 & & 1 & & & 4 & & & 6 & & & 1 & \\
\hline Western Jumping Mouse & & 1 & & 4 & 1 & & & & & & & & & \\
\hline House Mouse & & 4 & & 1 & 7 & 36 & & & & 2 & & & 7 & 1 \\
\hline Least Weasel & & 1 & & & & 1 & 2 & & & 1 & & & 1 & \\
\hline Lonq-tailed Weasel & & & & 1 & & & & & & & & & & \\
\hline Striped Skunk & & & & & & & & & & & 1 & & & \\
\hline
\end{tabular}

\begin{tabular}{|c|c|c|c|c|c|c|c|c|c|c|c|c|c|c|}
\hline Bird & 2 & 29 & 26 & 16 & 10 & 51 & 32 & & 1 & 27 & & 2 & 9 & 5 \\
\hline Grasshopper & & 11 & 6 & 1 & & 1 & & & & 5 & & & 1 & \\
\hline Water Beetle & & 1 & 1 & 6 & 1 & 10 & & & & & & & & \\
\hline Water Bug & & & 1 & & 1 & 2 & & 1 & & 2 & & & 4 & \\
\hline Insect & & & 1 & & & & 7 & & & 1 & & & & \\
\hline Beetle & 2 & 1 & 4 & 2 & & & & & & 1 & 2 & & & \\
\hline Fish & & 10 & & & & & 7 & & & 1 & & & & \\
\hline Snake & & 4 & & & & & & & & & & & 1 & \\
\hline Anuran & & 1 & 14 & 1 & & 56 & 1 & & & 1 & & & 1 & 3 \\
\hline Salamander & & 4 & 5 & 2 & & 4 & 17 & 4 & & 14 & 2 & & 3 & 3 \\
\hline
\end{tabular}




\subsection{Prairie Shrew (Sorex haydeni)}

Petersen and Roberts (1999) recently summarised the known distribution of prairie shrews in Alberta. They found the species to occur over the grassland and parkland natural regions with a few records outside these areas. A specimen from along the Waterton River (Table A11) represents a new marginal record for southwestern Alberta, but is within the expected habitat and distribution of the species.

Shrews occur irregularly in great horned owl pellets. In the samples examined here, prairie shrews tend to occur with fairly large numbers of sagebrush voles (Table A7, A14). Earlier results (Schowalter and Digby 1997, 1999) show a similar relationship. However, the converse is not the case as the sites with the greatest number of sagebrush voles have few shrews (Table A2, A3, A6, A10, A14). Habitat use by the two species is not well understood; however, researchers should be aware of a possible shared use of certain habitats.

\subsection{Water Shrew (Sorex palustris)}

The water shrew from a pellet collected near Madden (Table A13) is a new marginal record for the species in the province but is well within the projected range reported by Smith (1993).

\section{$\underline{4.3 \text { Nuttall's Cottontail (Sylvilagus nuttallii) }}$}

As noted by Smith (1992) and Schowalter and Digby (1999), cottontails are more widely spread than casual observation would suggest. The remains of a juvenile cottontail were recovered from along the Waterton River north of Glenwood (Table A11). The specimen is approximately $43 \mathrm{~km}$ northwest of the nearest record reported by Smith (1993). The habitat, treed areas near the river with considerable brush, is suitable for cottontails. That they were not seen here earlier may be due to their not being conspicuous when they occur in low numbers.

\subsection{Northern Pocket Gopher (Thomomys talpoides)}

Northern pocket gophers are spreading rapidly in southwestern Alberta (Bryan Phillips, MD. of Cardston, personal comm. August 1999). The extent of their current distribution has not been adequately mapped; however, it is well beyond that indicated by Smith (1993). The record from northwest of Leavitt (Table A10) is from outside the recognised range. However, pocket gophers are established well to the east of this location (Jamie Meeks, County of Warner, personal communication, August 1999).

\subsection{Olive-backed Pocket Mouse (Perognathus fasciatus) - Sensitive}

A single pocket mouse was recovered from the large sample of mammals in pellets from Middle Coulee (Table A2), approximately $5 \mathrm{~km}$ east of the Milk River Ridge Reservoir. The location is approximately $40 \mathrm{~km}$ west of the nearest previous record as reported by 
Smith (1993). Previous records of pocket mice in great horned owl pellets have been from areas with sandier soil than this location (Schowalter 2000, Schowalter and Digby 1999). Areas of sandy soil in the region might be profitably examined for this species.

\subsection{Deer Mouse (Peromyscus maniculatus)}

Specimens of deer mouse from north of Cowley (Table A14) had unusually large teeth. A representative sample was placed in the University of Alberta Museum of Zoology.

\subsection{Northern Grasshopper Mouse (Onychomys leucogaster)}

Earlier sampling has shown that grasshopper mice are more abundant and widely distributed in Alberta than trapping records would suggest (Schowalter 2000; Schowalter and Digby 1997, 1999; Smith 1992). Specimens of northern grasshopper mouse from east of Stavely (Table A6) represent a new marginal distribution record for the species. Possibly equally significant was the absence of specimens in sizeable samples from grassland habitat at Leavitt, Madden and north of Cowley. While the absence of a species is impossible to demonstrate, the lack of specimens suggests that the limit of this species' distribution is being approached.

Where grasshopper mice occurred, they were in the greatest number at locations where there were also large numbers of sagebrush voles. However, the distribution of sagebrush voles appears to extend beyond that of grasshopper mice on the western plains (though the reverse is the case elsewhere in Alberta (Schowalter 2000, Schowalter and Digby 1999)). Grasshopper mice were particularly abundant east of Stavely in an area of sandy soil that is also at the edge of their known distribution.

\subsection{Long-tailed Vole (Microtus longicaudus)}

Long-tailed voles were identified from northwest of Leavitt (Table A10) and near Madden (Table A13). The former is a new marginal record that, being from the plains, closes the gap at least ecologically between the records in the foothills and plains to the east (Smith 1993).

The record from Madden is approximately $64 \mathrm{~km}$ northeast of the closest record mapped by Smith (1993). Given the sporadic occurrence of long-tailed voles outside the mountains (Smith 1993), additional occurrences might be expected around Calgary and areas to the north and west.

\subsection{Prairie Vole (Microtus ochrogaster) - Status Undetermined}

Prairie voles have been one of the least frequently trapped of small mammals in Alberta (Smith 1993). The species has proven to be fairly abundant in some samples of great horned owl pellets from the Parkland biome (Schowalter 2000, Schowalter and Digby 1999). In the current samples, a single specimen from south of Cochrane (Table A12) is approximately $67 \mathrm{~km}$ south of previously mapped records. A larger sample of 23 was 
identified from great horned owl pellets from northwest of Madden (Table A13). That occurrence to some extent fills the gap between previous records and the one south of Cochrane and, with previous data, indicates that prairie voles attain modest abundance in areas of the Parkland.

\subsection{Sagebrush Vole (Lemmiscus curtatus)}

Sagebrush voles occurred widely and often in fair abundance in the samples described here. That they occur in some numbers at north of Cowley (Table A14) and northwest of Leavitt (Table A10), which represent marginal records, suggests that the species is to be expected in favourable habitats to the west of its currently understood distribution.

On the western plains, sagebrush voles are generally the third most abundant small mammal after deer mice and meadow voles. At two dry sandy locations, east of Stavely (Table A6) and east of Carmengay (Table A3), sagebrush voles were the second most abundant species after deer mice. At those locations, the proportion of sagebrush voles in the samples is increased while that of meadow voles appears to be reduced.

Sagebrush voles were not identified in the sample from northwest of Madden (Table A13). The area appeared to offer suitable habitat. Further samples in the region are needed to determine whether the species does not occur in the area.

\subsection{Other Species}

Differences in the proportions of prey items identified between sites were noted. Of interest are the relatively high numbers of fish from the Middle Coulee (Table A2) and Little Bow (Table A7) locations. This is partially the result of opportunity, as the former site is near an irrigation canal and the latter is on the Little Bow River. However, frequent predation of fish by great horned owls on the plains of Alberta has been found at only one other site, on the Rosebud River (Schowalter, unpublished data). Those instances, and similarly irregular occurrences of a large number of anurans, such as at the site east of Stavely, suggest individual differences in hunting preferences of owls. The possible effects of such preferences on the capture of small mammals are unknown but need to be kept in mind while interpreting results such as those presented here.

The proportion of birds in the samples also differed. Despite not having the greatest number of birds identified, the owls at the site east of Carmengay doubtless consumed the greatest biomass of birds present in the samples. Larger birds, including numerous magpies, partridges and rock doves predominated; whereas small (and difficult to identify) individuals comprised the bulk of birds at the other sites. That was particularly true of the sample from east of Stavely.

Among small mammals, western jumping mouse was very uncommon in the samples, as has been the case with previous studies of samples from the plains and parklands (Schowalter and Digby 1997, 1999; Smith 1992). An area of further research would be 
to determine the actual abundance of this (and other) species compared to what is captured by the owls.

\subsection{DISCUSSION}

The research described here produced nine significant distribution records of small mammals on the western plains of Alberta and several other records of interest. Sagebrush vole and northern grasshopper mouse are, overall, fairly common in the samples. Similar results have been reported from other regions of the grasslands of Alberta (Schowalter 2000; Schowalter and Digby 1997, 1999; Smith 1981, 1992). These two species have been flagged as being of potential conservation concern (Alberta Environmental Protection 1996). Based on the results of owl pellet analyses, it is presumed likely that the species are difficult to capture using standard museum capture techniques and that they are actually relatively abundant. It is probable that populations of northern grasshopper mouse and sagebrush voles are secure in Alberta.

Petersen and Roberts (1999) similarly note that the prairie shrew populations are probably secure. While shrews occur somewhat sporadically in owl pellet samples examined, they occur in most samples, occasionally in number. That information supports the conclusion that prairie shrew populations are secure.

Collections of pellets referenced in publications by Smith $(1981,1992)$ and Schowalter and Digby $(1997,1999)$ intentionally targeted roosts in areas that had at least some native grassland preserved. General habitat associations of many species, including prairie shrew, pocket mouse, grasshopper mouse, meadow vole, long-tailed vole, sagebrush vole and prairie vole are suggested by the results.

Currently, the Alberta Conservation Association is undertaking analysis of a large group of samples from the plains and parkland (Lance Engley, personal communication, August 2000). It is hoped that the analysis will provide much-needed information on the occurrence of small mammals in disturbed habitats as well as more detailed data of the type reported here.

The success of this study in establishing distribution information and multiple records of otherwise infrequently encountered small mammals supports a continued and expanded effort in analysing owl pellets. However, sufficient data have accumulated to require a review and analysis of what has been accomplished. Such a review would provide a reference point and direction for further studies.

\subsection{MANAGEMENT IMPLICATIONS AND FUTURE DIRECTIONS}

Data from this and previous studies have contributed to the determination of the general status of sagebrush vole and grasshopper mouse (Gordon Court, Alberta Fisheries and Wildlife Management, pers. comm.). As well, new information on the distribution and 
abundance of prairie vole and olive-backed pocket mouse, both species of conservation concern, was found. Significant new location records of other species of small mammals were also established.

Of species identified as being of conservation concern, further investigation of owl pellets from the parkland biome are likely to produce information about the distribution and abundance of prairie voles.

For those species that appear to be frequently captured by great horned owls, it is probably possible to determine where they do not occur or at least are very uncommon. Opportunities to obtain convincing negative evidence about small mammal distributions are rare. A review and evaluation of the accumulated data is needed to identify gaps and could be the basis for further collection and analyses to investigate the occurrence of targeted species.

The analysis method used here is dependent upon access to old buildings. While information can be gained from examining pellets from nest sites, those pellets are necessarily seasonally restricted and will rarely accumulate over several years. Abandoned buildings suitable for owl roosting are steadily being torn down. Currently, it is not possible to find roost sites from which to collect pellets in some areas. It is likely that it will be possible to obtain relatively comprehensive, geographically representative samples for only a few more years. It is recommended that collections of pellets be made in poorly represented areas in the near future. 


\subsection{LITERATURE CITED}

Alberta Environmental Protection, Wildlife Management Division 1996. The status of Alberta wildlife. $43 \mathrm{pp}$.

Craighead, J.J., and F.C. Craighead, Jr. 1956. Hawks, owls and wildlife. Wildlife Management Institute, Washington, D.C. 443 pp.

Petersen, S.D., and W. Roberts. 1999. Notes on the abundance and distribution of prairie shrews (Sorex haydeni) in Alberta. Alberta Naturalist 29(2):24-27.

Schowalter, D. 2000. Results of analyses of Great Horned Owl pellets from Alberta. Report prepared for Alberta Environment, Fisheries and Wildlife Management Division. 14 pp.

Schowalter, D., and R. Digby. 1997. Distribution records of small mammals from Alberta from great horned owl pellets. Alberta Naturalist 27:32-36

Schowalter, D., and R. Digby. 1999. New distribution records of small mammals from Alberta from great horned owl pellets. Alberta Naturalist 29(4):82-83.

Smith, H.C. 1981. The distribution of mammals in southeastern Alberta as indicated by the analysis of owl pellets. Blue Jay 39(4):230-238.

Smith, H.C. 1992. Mammals of the Drumheller area. Provincial Museum of Alberta Natural History Occasional Paper No. 17. Edmonton, AB. 25pp.

Smith, H.C. 1993. Alberta mammals: an atlas and guide. The Provincial Museum of Alberta. Edmonton, AB. 238pp.

van Zyll de Jong, C.G. 1980. Systematic relationships of woodland and prairie forms of the common shrew, Sorex cinereus cinereus Kerr, and S.c. haydeni Baird, in the Canadian prairie provinces. Journal of Mammalogy 61:66-75. 
Appendix A. Site-specific Results and Descriptions 
Locality Name: East of Hayes

Table A1. Species and number of specimens from great horned owl pellets from under bridge east of Hayes.

\begin{tabular}{lr}
\hline Species & Number \\
\hline Prairie Shrew & 1 \\
Cottontail & 1 \\
Deer Mouse & 1 \\
\hline Total Mammals & 3 \\
\hline & \\
Bird & 2 \\
Beetle & 2 \\
\hline
\end{tabular}

Legal: SW 4-13-13 W4

GPS: Not recorded

Elevation: Not recorded

Descriptive: Pellets from under bridge over Bow River on Secondary Highway 524 east of Hayes, Alberta.

Habitat: Area in river valley of grassland with cottonwoods along river. Great horned owl on hawk's nest in cottonwood. Second adult bird flew from tree nearby when site approached. No pellets were found under or near nest. 
Table A2. Prey remains from great horned owl pellets collected in Middle Coulee.

\begin{tabular}{lr}
\hline Species & Number \\
\hline Prairie Shrew & 1 \\
Dusky Shrew & 1 \\
Prairie or Common Shrew & 1 \\
Jackrabbit & 2 \\
Richardson's G.S. & 5 \\
Pocket Mouse & 1 \\
Deer Mouse & 399 \\
Grasshopper Mouse & 21 \\
Meadow Vole & 37 \\
Sagebrush Vole & 30 \\
Muskrat & 1 \\
Western Jumping Mouse & 1 \\
House Mouse & 4 \\
Least Weasel & 1 \\
\hline Total Mammals & 505 \\
\hline & \\
Bird & 29 \\
Grasshopper & 11 \\
Water Beetle & 1 \\
Beetle & 1 \\
Fish & 10 \\
Snake & 4 \\
Anuran & 1 \\
Salamander & 4 \\
\hline
\end{tabular}

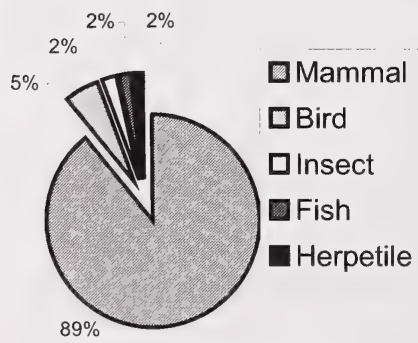

Figure A1. Percentages of major prey groups identified from great horned owl pellets collected from Middle Coulee.

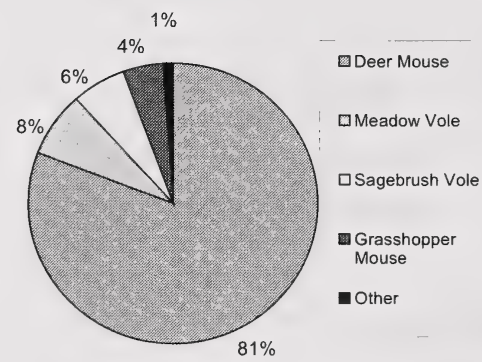

Figure A2. Percentages of mouse and vole species identified from great horned owl pellets collected from Middle Coulee.

Locality Name: Middle Coulee

Legal Location: NE31- 4-18 W4

GPS: 12397484 E: 54 66699N

Elevation: 998 m

Habitat: Barn is at base of north bank of Middle Coulee. A creek runs strongly through the valley and about $30 \mathrm{~m}$ from barn. Water for stream comes from Milk River Ridge Reservoir, which is about $5 \mathrm{~km}$ to west of site. With the exception of a grove of non-native trees, the valley is grassland. Areas of the valley floor have been cultivated in the past, but have reverted to grassland. The land surrounding the coulee is extensively cultivated.

Roost in loft of old barn built over spring. Considerable bone in loft from broken down pellets indicates that the roost had been in use for many years. Two owls present in loft. Partially eaten Richardson's ground squirrel draped over beam in loft.

Notes: Of special interest at this site is the occurrence of a single specimen of pocket mouse well to the west of previously known records. 
Table A3. Numbers of identified prey items from great horned owl pellets east of Carmengay.

\begin{tabular}{lr}
\hline Species & Number \\
\hline Prairie Shrew & 2 \\
Prairie or Common Shrew & 1 \\
Cottontail & 2 \\
Jackrabbit & 1 \\
Richardson's G.S. & 7 \\
Deer Mouse & 168 \\
Grasshopper Mouse & 28 \\
Meadow Vole & 20 \\
Sagebrush Vole & 40 \\
\hline Total Mammals & 269 \\
\hline & \\
Bird & 26 \\
Grasshopper & 6 \\
Water Beetle & 1 \\
Water Bug & 1 \\
Insect & 1 \\
Beetle & 4 \\
Anuran & 14 \\
Salamander & 5 \\
\hline
\end{tabular}

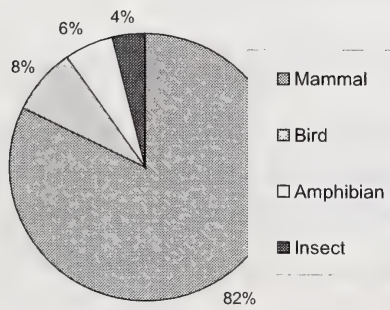

Figure A3. Percentages of major prey groups identified from great horned owl pellets collected east of Carmengay.

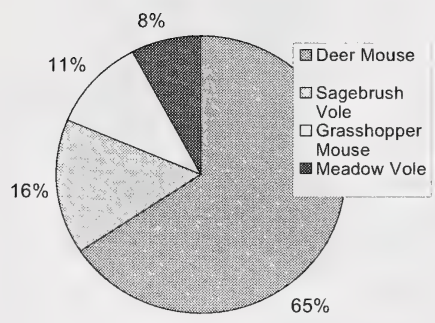

Figure A4. Percentages of mouse and vole species identified from great horned owl pellets collected east of Carmengay.

Location Name: East of Carmengay

Legal: 6-14-22 W4

GPS: Incorrectly recorded

Elevation: $887 \mathrm{~m}$

Habitat: Abandoned farmyard approximately $5 \mathrm{mi}$ east of Carmengay with Manitoba maple and caragana on two sides. Small pond in northeast portion of yard. Pellets collected from barn loft, grain bin and old shop.

Area to south, west, and north of yard is sandy grassland. Land to west appears to have been cultivated at one time. Land to east is tame hay.

Notes: Two adult and one juvenile owl seen. One adult and the juvenile were roosted in shop.

Feathers from sharp-tailed grouse, numerous magpies, gray partridge, pheasant, and ducks were noted while collecting pellets.

Noteworthy at this site is that grasshopper mice and sagebrush voles are more numerous than meadow voles. 
Table A4. Numbers of prey from great horned owl pellets from north of Cluny.

\begin{tabular}{lr}
\hline Species & Number \\
\hline Prairie Shrew & 1 \\
Cottontail & 3 \\
Jackrabbit & 1 \\
Richardson's G.S. & 2 \\
Deer Mouse & 195 \\
Grasshopper Mouse & 5 \\
Meadow Vole & 22 \\
Sagebrush Vole & 15 \\
Muskrat & 1 \\
Western Jumping Mouse & 4 \\
House Mouse & 1 \\
Long-tailed Weasel & 1 \\
\hline Total Mammals & 251 \\
\hline
\end{tabular}

\begin{tabular}{lr} 
Bird & 16 \\
Grasshopper & 1 \\
Water Beetle & 6 \\
Beetle & 2 \\
Anuran & 1 \\
Salamander & 2 \\
\hline
\end{tabular}

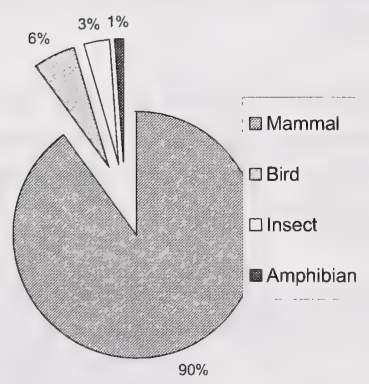

Figure A5. Percentages of major prey groups identified from great horned owl pellets collected north of Cluny.

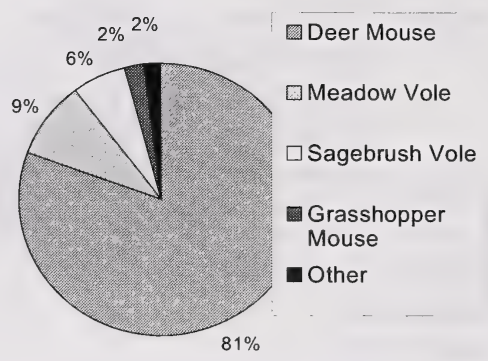

Figure A6. Percentages of mouse and vole species identified from great horned owl pellets collected north of Cluny.

Locality Name: North of Cluny

Legal: NE 9-23-21 W4

GPS: 12368837 E: $5645898 \mathrm{~N}$

Elevation: $858 \mathrm{~m}$

Habitat: Abandoned yard with several buildings utilized by owls. About 80 acres of natural habitat in shallow coulee. Area extensively invaded by crested wheat, brome and non-native trees. Most of area has heavy, if short, cover. Surrounding area intensively cultivated. Limited areas of banks very arid with cactus and sage.

Notes: Two Juvenile owls seen on site. 
Table A5. Species and number of prey items from great horned owl pellets SW of Standard.

\begin{tabular}{lr}
\hline Species & Number \\
\hline Prairie or Common Shrew & 1 \\
Richardson's Ground Squirrel & 5 \\
Deer Mouse & 190 \\
Grasshopper Mouse & 7 \\
Meadow Vole & 28 \\
Sagebrush Vole & 1 \\
Western Jumping Mouse & 1 \\
House Mouse & 7 \\
\hline Total Mammals & 240 \\
\hline Bird & \\
Water Beetle & 10 \\
Water Bug & 1 \\
Salamander & 1 \\
\hline
\end{tabular}

Figure A7. Percentages of major prey groups identified from great horned owl pellets collected from SW of Standard.

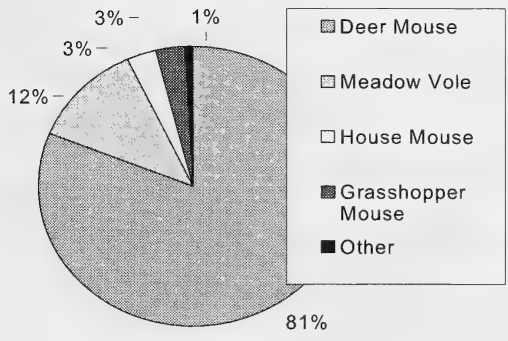

Figure A8. Percentages of mouse and vole species identified from great horned owl pellets collected from SW of Standard.

Location: SW Standard, Alberta.

Legal: SW 19-24-22 W4

GPS: 12354 914E: 56 56106N

Elevation: $887 \mathrm{~m}$

Habitat: Pellets from abandoned bins just east of occupied yard with large trees. Irrigation canal immediately behind bins and between bins and trees. Area to east and north is tame hay that appears to have been extensively grazed. To west of yard west of bins are a few acres of native grass, which is intensely grazed. Further to north on same quarter is another small area of native grass. Land across road to south is cultivated.

Notes: Landowner picked up a great horned owl here in January or February that was unable to fly. He turned the bird over to the local wildlife office. 
Table A6. Prey remains identified from great horned owl pellets collected east of Stavely.

\begin{tabular}{lr}
\hline Species & Number \\
\hline Common Shrew & 2 \\
Prairie Shrew & 1 \\
Dusky Shrew & 1 \\
Silver-haired Bat & 1 \\
Jackrabbit & 8 \\
Richardson's G.S. & 5 \\
Deer Mouse & 280 \\
Grasshopper Mouse & 88 \\
Meadow Vole & 26 \\
Sagebrush Vole & 97 \\
House Mouse & 36 \\
\hline Total Mammals & 546 \\
\hline & \\
Bird & 51 \\
Grasshopper & 1 \\
Water Beetle & 10 \\
Water Bug & 2 \\
Anuran & 56 \\
Salamander & 4 \\
\hline
\end{tabular}

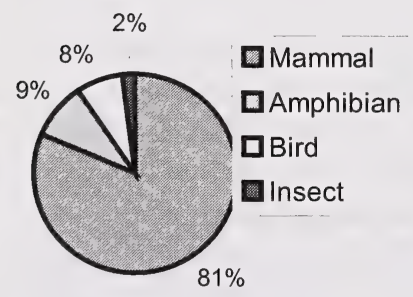

Figure A9. Percentages of major prey groups identified from great horned owl pellets collected from east of Stavely.

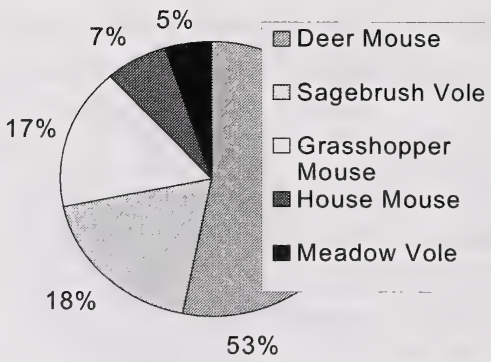

Figure A10. Percentages of mouse and vole species identified from great horned owl pellets collected from east of Stavely.

Location Name: East of Stavely

Legal: NE 9-14-25 W4

GPS: 12332 128E; 5559573N

Elevation: 1046 m

Habitat: Owl roost in abandoned grain bin. Owl seen in window of bin. Bin in abandoned yard with scrubby Manitoba maples and caragana. Area very sandy, tame hay to north and east, about 30 acres of native grass in and around yard. Area to south of grass and to east cultivated.

Notes: Sample has unusually high number of grasshopper mice and sagebrush voles. Meadow voles make up a smaller percentage of the small mammals than is usual. That may be due to the dry, sandy environment. The large number of anurans indicates that there are one or more water bodies in the hunting range of the owls that occupied the roosts. The water body may not be a permanent one as none was observed during the visit. Spring runoff had been unusually low this year. 
Table A7. Prey remains identified from great horned owl pellets collected from an abandoned yard on the Little Bow River.

\begin{tabular}{lr}
\hline Species & Number \\
\hline Common Shrew & 5 \\
Prairie Shrew & 12 \\
Prairie or Common Shrew & 3 \\
Dusky Shrew & 3 \\
Jackrabbit & 7 \\
Richardson's G.S. & 6 \\
Deer Mouse & 228 \\
Grasshopper Mouse & 21 \\
Meadow Vole & 65 \\
Sagebrush Vole & 15 \\
Muskrat & 4 \\
Least Weasel & 2 \\
\hline Total Mammals & 372 \\
\hline & \\
Bird & 32 \\
Insect & 7 \\
Fish & 7 \\
Anuran & 1 \\
Salamander & 17 \\
\hline
\end{tabular}

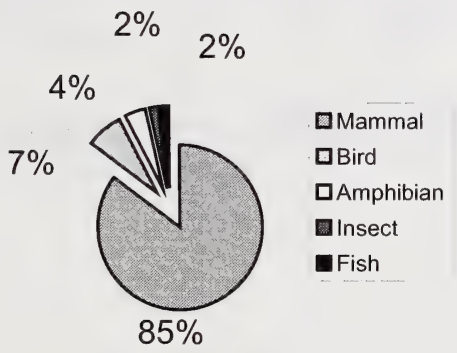

Figure A11. Percentages of major prey groups identified from great horned owl pellets collected from Little Bow River east of Stavely.

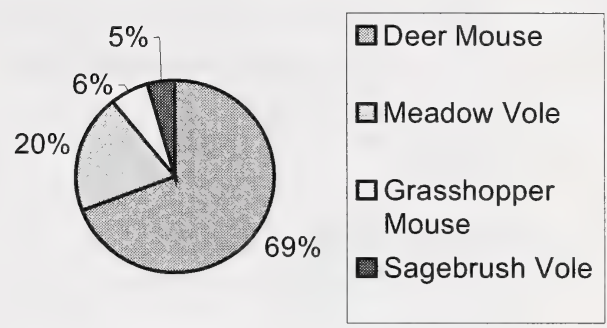

Figure A12. Percentages of mouse and vole species in great horned owl pellets collected from Little Bow River east of Stavely.

Location Name: Little Bow

Legal: NE 11-14-25 W4

GPS: 12335 445E; 5559 365N

Elevation: $935 \mathrm{~m}$

Habitat: Location is abandoned yard in valley of Little Bow River adjacent to river. There is a clump of large nonnative poplars on west side of yard. There are no other trees, though northfacing slope of valley near house is heavily covered with shrubs.

Valley is grassland. Some of flatter parts appear to have been cultivated in past. Area surrounding valley is cultivated, hayland, or native grassland. Soils in valley and surrounding area appear to be quite sandy.

Notes: There were two adult owls in trees and one young owl on a hawk's nest. 
Table A8. Prey remains from great horned owl pellets collected near

Swalwell.

\begin{tabular}{lr}
\hline Species & Number \\
Deer Mouse & 16 \\
Meadow Vole & 2 \\
\hline Total Mammals & 18 \\
\hline & \\
Water Bug & 1 \\
Salamander & 4 \\
\hline
\end{tabular}

Locality Name: Swalwell

Legal: SE 33-30-24 W4.

Habitat: Pellets from old shed in heavily grassed coulee. Much brome invasion and heavy growth on bottom of coulee. Road allowances near building dominated by brome. Some brush on slopes, little remaining natural habitat in area. Coulee grassland surrounded by cultivated fields. 
Table A9. Prey remains from great horned owl pellets collected south of Mountain View.

\begin{tabular}{lr}
\hline Species & Number \\
\hline Meadow Vole & 2 \\
Sagebrush Vole & 1 \\
\hline Total Mammals & 3 \\
\hline
\end{tabular}

Bird 1

Site Name: Mountain View

Legal: NE 32-4-18 W4

GPS: 12309 221E; 5443 974N

Elevation: $1334 \mathrm{~m}$

Habitat: Sample from large barn loft with many racoon droppings.

Surrounding area mixed native grassland and tame grass. All grazed. Area has mix of aspen, willow and rows of non-native poplars. At least two reed-rich reservoirs near barn and stream course approximately $200 \mathrm{~m}$ to south and southeast.

Species Comments: The sagebrush vole is a marginal record. 
Table A10. Prey remains from great horned owl pellets collected northwest of Leavitt.

\begin{tabular}{lr}
\hline Species & Number \\
\hline Prairie or Common Shrew & 3 \\
Richardson's G.S. & 4 \\
Pocket Gopher & 34 \\
Deer Mouse & 118 \\
Meadow Vole & 38 \\
Long-tailed Vole & 1 \\
Sagebrush Vole & 22 \\
Muskrat & 6 \\
House Mouse & 2 \\
Least Weasel & 1 \\
\hline Total Mammals & 229 \\
\hline & \\
Bird & 27 \\
Grasshopper & 5 \\
Water Bug & 2 \\
Insect & 1 \\
Beetle & 1 \\
Fish & 1 \\
Anuran & 1 \\
Salamander & 14 \\
\hline
\end{tabular}

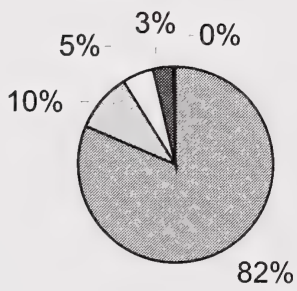

$\square$ Mammal

$\square$ Bird

$\square$ Amphibian

Insect

Fish

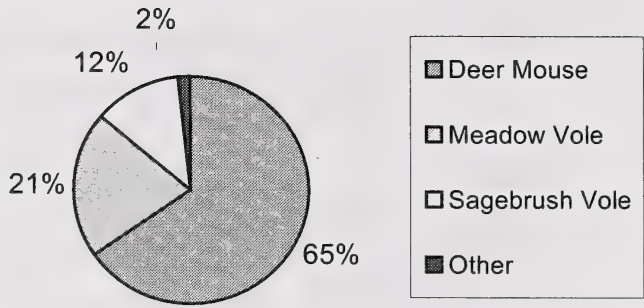

Figure A14. Percentages of mouse and vole species identified from great horned owl pellets collected from northwest of Leavitt.

Locality Name: Northwest of Leavitt.

Legal:NW 31-3-27 W4

GPS:12 309 397E; 5458 291N

Elevation: $1186 \mathrm{~m}$

Habitat: Pellets collected in old auction barn. Most of surrounding area tame grass and hay. Some areas of cultivation. Large irrigation ditch runs near buildings.

Notes: Sagebrush vole and long-tailed vole are marginal records.

Figure A13. Percentages of major prey groups identified from great horned owl pellets collected from northwest of Leavitt. 
Table A11. Prey remains from great horned owl pellets collected from along Waterton River.

\begin{tabular}{lr}
\hline Species & Number \\
\hline Common Shrew & 1 \\
Prairie or Common & 1 \\
Shrew & \\
Cottontail & 1 \\
Deer Mouse & 3 \\
Meadow Vole & 16 \\
Striped Skunk Juv. & 1 \\
\hline Total Mammals & 23 \\
\hline & \\
Beetle & 2 \\
Salamander & 2 \\
\hline
\end{tabular}

Figure A15. Percentages of major prey groups identified from great horned owl pellets collected from along Waterton River.

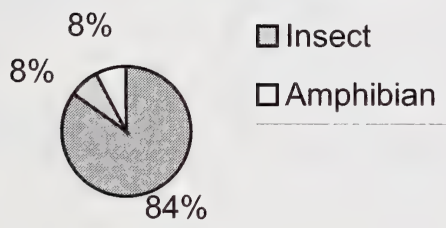

Site Name: Waterton River

Legal Location: 36-5-27 W4

GPS: 12318 706E; 5478 259N

Date: 6 May 2000

Description: Small sample of pellets from large old barn in valley of Waterton River at bridge on $2^{\text {nd }}$ Highway 810 north of Glenwood.

Habitat: Immediate area of barn dominated by cottonwoods; some areas of brush. Area away from river grazed grassland.

Notes: Cottontail specimens have not been taken in the area before. 
Table A12. Prey remains from great horned owl pellets from south of Cochrane.

\begin{tabular}{lr}
\hline Species & Number \\
\hline Pocket Gopher & 1 \\
Deer Mouse & 4 \\
Meadow Vole & 1 \\
Prairie Vole & 1 \\
\hline Total Mammals & 7 \\
\hline & \\
Bird & 2 \\
\hline
\end{tabular}

Site Name: South of Cochrane

Legal Location: NE 35-24-4 W5

GPS: 11677 981E; $5663471 \mathrm{~N}$

Elevation: 1273 m

Habitat: Abandoned yard northeast of junction of Highways 1 and 22. Location in abandoned grain bin near top of hill. Well-treed farmyard just immediately to east of site. Aspen clumps in area. Yard has well-developed non-native poplars, Manitoba maple and caragana. Area has heavy grass where not grazed down.

Pond about $1 \mathrm{~km}$ west of site at base of hill.

Notes: Occurrence of prairie vole represents considerable range extension. Area is of aspen parkland and therefore suitable habitat. 
Table A13. Prey items identified from great horned owl pellets collected from NW Madden.

\begin{tabular}{|c|c|}
\hline Species & Number \\
\hline Common Shrew & 4 \\
\hline Water Shrew & 1 \\
\hline Richardson's G.S. & 3 \\
\hline Pocket Gopher & 29 \\
\hline Deer Mouse & 130 \\
\hline Meadow Vole & 49 \\
\hline Long-tailed Vole & 2 \\
\hline Prairie Vole & 23 \\
\hline Muskrat & 1 \\
\hline House Mouse & 7 \\
\hline Least Weasel & 1 \\
\hline Total Mammals & 250 \\
\hline Bird & 9 \\
\hline Grasshopper & 1 \\
\hline Water Bug & 4 \\
\hline Snake & 1 \\
\hline Anuran & 1 \\
\hline Salamander & 3 \\
\hline
\end{tabular}

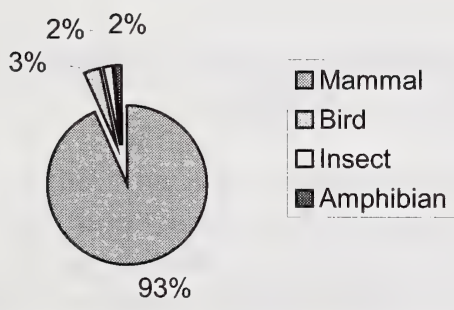

Figure A16. Percentages of major prey groups identified from great horned owl pellets collected from NW Madden.

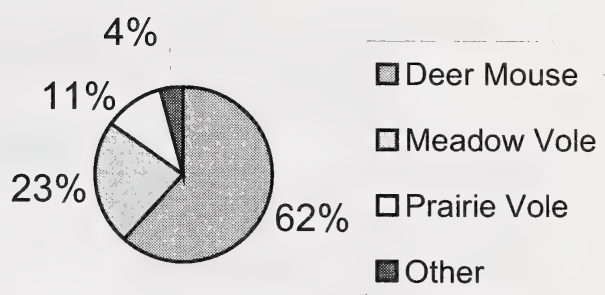

Figure A17. Percentages of mouse and vole species identified from great horned owl pellets collected from NW Madden.

Locality Name: NW Madden

Legal: 12-29-3 W5

GPS: 11687 186E; 5705 422N

Habitat: Pellets from old barn loft. Barn being torn down. Area is abandoned yard with cultivated field to north. East and south is shallow valley with native grass with some aspen. Grass heavily grazed. Area of yard invaded by brome.

Notes: Many pocket gopher mounds around yard. Prairie vole record is out of previously known range and of particular interest as there are so many. Long-tailed vole represents a new distribution record for species. 
Table A14. Prey remains from great horned owl pellets from north of Cowley.

\begin{tabular}{lr}
\hline Species & Number \\
\hline Common Shrew & 1 \\
Prairie Shrew & 11 \\
Common or Prairie Shrew & 2 \\
Dusky Shrew & 11 \\
Snowshoe Hare & 2 \\
Pocket Gopher & 8 \\
Deer Mouse & 114 \\
Meadow Vole & 53 \\
Sagebrush Vole & 37 \\
House Mouse & 1 \\
\hline Total Mammals & 232 \\
\hline & \\
Bird & 5 \\
Anuran & 3 \\
Salamander & 3 \\
\hline
\end{tabular}

Figure A18. Percentages of major prey groups identified from great horned owl pellets collected north of Cowley.

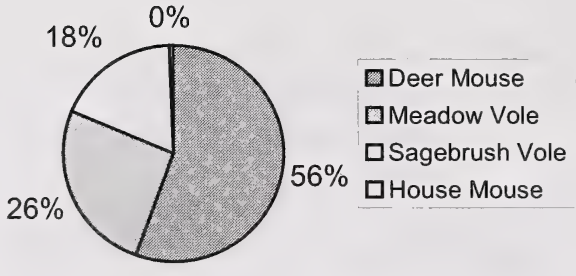

Figure A19. Percentages of mouse and vole species identified from great horned owl pellets collected north of Cowley.

Locality Name: North of Cowley

Legal: SE 24-9-2 W5

GPS: 11706 165E; 5514 745N

Elevation: $1295 \mathrm{~m}$

Habitat: Old grain bin with native pasture to east and tame hay and grassland to north. South is cultivated field.

Location is on west edge of Porcupine Hills north of Cowley.

Notes. Richardson's ground squirrel very common, however not present in sample. Columbian ground squirrels occur in small number in pasture $2 \mathrm{~km}$ to north; however, were not observed near collection site. The sagebrush voles represent a marginal record. Their abundance here suggests that they should be common in suitable habitat west of the Porcupine Hills and should be looked for in valleys into mountains to west. 
Appendix B. Voucher Specimens Submitted to the University of Alberta Museum of Zoology 
Table B1. Specimen numbers of voucher specimens placed in the collections of the University of Alberta Museum of Zoology of significant small mammal discoveries recovered from great horned owl pellets.

\begin{tabular}{|c|c|c|c|}
\hline UAMZ Number & Species & Location & $\begin{array}{l}\text { Collection } \\
\text { Date }\end{array}$ \\
\hline 10013 & $\begin{array}{l}\text { Water Shrew } \\
\text { Sorex palustris }\end{array}$ & $\begin{array}{l}\text { 12-29-3 W5 } \\
\text { NW Madden, AB }\end{array}$ & 9 April 2000 \\
\hline 10010 & $\begin{array}{l}\text { Nuttall's Cottontail } \\
\text { Sylvilagus nuttalli }\end{array}$ & $\begin{array}{l}\text { W } 1 / 236-5-27 \text { W4 } \\
\text { Bridge on } 2^{\text {nd }} \text { Hwy } \\
810 \text { over Waterton } \\
\text { River. AB }\end{array}$ & 6 May 2000 \\
\hline 10016 & $\begin{array}{l}\text { Olive-backed Pocket } \\
\text { Mouse } \\
\text { Perognathus fasciatus }\end{array}$ & $\begin{array}{l}\text { Middle Coulee } \\
\text { NE 31-4-18 W4 }\end{array}$ & 5 May 2000 \\
\hline 10015 & $\begin{array}{l}\text { Deer Mouse } \\
\text { Peromyscus maniculatus }\end{array}$ & $\begin{array}{l}\text { SE 24-9-2 W5 } \\
\text { N. of Cowley, AB }\end{array}$ & 28 June 2000 \\
\hline 10006 & $\begin{array}{l}\text { Northern Grasshopper } \\
\text { Mouse } \\
\text { Onychomys leucogaster }\end{array}$ & $\begin{array}{l}\text { Middle Coulee } \\
\text { NE 31-4-18 W4 }\end{array}$ & 5 May 2000 \\
\hline 10018 & $\begin{array}{l}\text { Northern Grasshopper } \\
\text { Mouse } \\
\text { Onychomys leucogaster }\end{array}$ & $\begin{array}{l}\text { East of Stavely } \\
\text { NE 9-14-25 W4 }\end{array}$ & 6 May 2000 \\
\hline 10012 & $\begin{array}{l}\text { Long-tailed Vole } \\
\text { Microtus longicaudus }\end{array}$ & $\begin{array}{l}\text { NW 31-3-27 W4 } \\
\text { NW Leavitt, AB }\end{array}$ & 6 May 2000 \\
\hline 10007 & $\begin{array}{l}\text { Long-tailed Vole } \\
\text { Microtus longicaudus }\end{array}$ & $\begin{array}{l}\text { 12-29-3 W5 } \\
\text { NW Madden, AB }\end{array}$ & 9 April 2000 \\
\hline 10009 & $\begin{array}{l}\text { Prairie Vole } \\
\text { Microtus ochrogaster }\end{array}$ & $\begin{array}{l}\text { NE 35-24-4 W5 } \\
\text { S. of Cochrane, AB }\end{array}$ & 28 June 2000 \\
\hline 10017 & $\begin{array}{l}\text { Prairie Vole } \\
\text { Microtus ochrogaster }\end{array}$ & $\begin{array}{l}\text { 12-29-3 W5 } \\
\text { NW Madden, AB }\end{array}$ & 9 April 2000 \\
\hline 10014 & $\begin{array}{l}\text { Sagebrush Vole } \\
\text { Lemmiscus curtatus }\end{array}$ & $\begin{array}{l}\text { NW 31-3-27 W4 } \\
\text { NW Leavitt, AB }\end{array}$ & 6 May 2000 \\
\hline 10011 & $\begin{array}{l}\text { Sagebrush Vole } \\
\text { Lemmiscus curtatus }\end{array}$ & $\begin{array}{l}\text { SE 24-9-2 W5 } \\
\text { North of Cowley, AB }\end{array}$ & 28 June 2000 \\
\hline 10008 & $\begin{array}{l}\text { Sagebrush Vole } \\
\text { Lemmiscus curtatus }\end{array}$ & $\begin{array}{l}\text { 18-2-27 W4 } \\
\text { S. of Mountain View, } \\
\text { AB }\end{array}$ & 6 May 2000 \\
\hline
\end{tabular}




\section{List of Titles in This Series}

(as of May 2001)

No. 1 Alberta species at risk program and projects 2000-2001, by Alberta Fisheries and Wildlife Management Division. (2001)

No. 2 Survey of the peregrine falcon (Falco peregrinus anatum) in Alberta, by R. Corrigan. (2001)

No. 3 Distribution and relative abundance of the shortjaw cisco (Coregonus zenithicus) in Alberta, by M. Steinhilber and L. Rhude. (2001)

No. 4 Survey of the bats of central and northwestern Alberta, by M.J. Vonhof and D. Hobson. (2001)

No. 52000 survey of the Trumpeter Swan (Cygnus buccinator) in Alberta, by M.L. James and A. James. (2001)

No. 6 2000/2001 Brassy Minnow inventory at Musreau Lake and outlet, by T. Ripley. (2001)

No. 7 Colonial nesting waterbird survey in the Northwest Boreal Region-2000, by M. Hanneman and M. Heckbert. (2001)

No. 8 Burrowing owl trend block survey and monitoring - Brooks and Hanna areas, by D. Scobie and R. Russell. (2000)

No. 9 Survey of the Lake Sturgeon (Acipenser fulvescens) fishery on the South Saskatchewan River, Alberta (June-September, 2000), by L.A. Winkel. (2000)

No. 10 An evaluation of grizzly bear-human conflict in the Northwest Boreal Region of Alberta (19912000) and potential mitigation, by Teresa Augustyn. (2001)

No. 11 Harlequin duck monitoring in the Northern East Slopes of Alberta: 1998-2000 preliminary results, by Jeff Kneteman and Anne Hubbs. (2000)

No. 12 Distribution of selected small mammals in Alberta, by L. Engley and M. Norton. (2001)

No. 13 Northern leopard frog reintroduction. Raven River - Year 2 (2000), by Kris Kendell. (2001)

No. 14 Cumulative effects of watershed disturbances on fish communities in the Kakwa and Simonette watersheds. The Northern Watershed Project. Study 3 Progress report, by T. Thera and A. Wildeman. (2001)

No. 15 Harlequin duck research in Kananaskis Country in 2000, by C.M. Smith. (2001)

No. 16 Proposed monitoring plan for harlequin ducks in the Bow Region of Alberta, by C.M. Smith. (2001)

No. 17 Distribution and relative abundance of small mammals of the western plains of Alberta as determined from great horned owl pellets, by D. Schowalter. (2001) 



National Library of Canada
Bibliothèque nationale du Canada

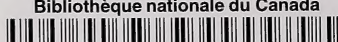

3 3286525459570 